\title{
Adrenal Medullary Autografts in Anterior Eye Chamber, Lateral Ventricle and Striatum of Adult Rats: A Long Term Study
}

\author{
Ashok Kumar Shetty, Gomathy Gopinath and P.N. Tandon \\ National Neural Transplant Unit, All India Institute of Medical Sciences, New Delhi-110029, India
}

\begin{abstract}
SUMMARY
The neurobiological basis for the short-term recovery in Parkinson's patients and experimental animals grafted with adrenal medulla is not yet clear. Structural details of the grafted chromaffin cells are also not available. In the present study, autografts of adrenal medulla in the anterior eye chamber, lateral ventricle and striatum of adult rats were studied for $\mathbf{3 6 0}$ days. Though a large number of cells degenerated, a few healthy chromaffin cells survived up to 360 days in the anterior eye chamber. In the ventricular and striatal regions, cells degenerated more rapidly, and a few surviving cells were seen only up to 120 and 150 days, respectively. Degeneration of the cells was evident from the alteration of the cytoplasmic granules, appearance of vacuoles and lysosomes, rapid decline in the number of TH and DBH positive cells and diffusion of enzymes in the intercellular region. Only lymphocytes and connective tissue cells were seen in the ventricle after 120 days, while outlines of a few chromaffin cells and background fluorescence were still evident in the striatum up to 150 days. In some of the intrastriatal transplants, morphologically identifiable Schwann cells were present and, in one transplant, there was evidence of myelination of axons by Schwann cells. These axons were obviously derived from the adjacent host tissue. From the findings it has been concluded that
\end{abstract}

Reprint address:

Professor Gomathy Gopinath

Department of Anatomy

All India Institute of Medical Sciences

New Delhi 110029, India autografts of adrenal medulla survive for only a limited period of time on transplantation to the central nervous system and anterior eye chamber. Survival seemed to be better in the anterior eye chamber than at the sites preferentially chosen for treating Parkinson's patients or experimental animals.

Key words: Adrenal medulla graft; Parkinson's disease; transplantation; anterior eye chamber; striatum; transplant morphology.

\section{INTRODUCTION}

The chromaffin cells of adrenal medulla, known for producing dopamine as an intermediary in the synthetic pathway of epinephrine $/ 19 /$, are used for grafting in rats and monkeys to reverse the deficits induced by chemical denervation of the striatum $13,9,10,12,20,25,26 /$. Results of these experiments prompted the use of adrenal medulla autografts in the treatment of Parkinson's patients $/ 2,16-18 /$. Only moderate recovery of short duration is reported so far in a small proportion of patients $/ 15,16 /$. The neurobiological basis of such recovery is still unexplained. Survival of allografts of chromaffin cells in the striatum of rats denervated chemically and amelioration of some of the deficits are reported in some studies by using fluorescence histochemistry and immunolabelling $/ 8,12 /$. Continued survival of grafted chromaffin cells was demonstrated by Stromberg et al. $/ 25,26 /$ only by the infusing of NGF into the implant site. Hansen et al. /14/ reported complete degeneration of the 
autografted adrenal medullary cells by one month in Cebus monkeys treated with MPTP. A recent autopsy report also shows complete degeneration of the adrenal medullary autograft in a Parkinson's patient /23/. These reports have brought to light the necessity for a more detailed basic study than hitherto exists, on the transplanted adrenal medullary cells. Transplanted adrenal chromaffin cells grafted to the anterior chamber of the eye were shown to have achieved neuronal characteristics with their processes innervating co-grafted cerebral cortex /21,22/. Similar observations were also recorded in culture of chromaffin cells in the absence of corticosteroids $/ 27-29 /$. The present study was undertaken to analyse the morphological details of the autografts of adrenal medulla in the anterior eye chamber, lateral ventricle and striatum.

\section{MATERIALS AND METHODS}

Adult Wistar rats of stock bred colony weighing 150 to $200 \mathrm{~g}$ were used in this study. The left adrenal gland, after removal from an anaesthetised (ketamine, $10 \mathrm{mg} / \mathrm{kg}$ body weight) rat, was dissected to free the medulla from the cortex in sterile lactated Ringer's solution under an operation microscope. Standard techniques were used to transplant the medullary grafts into the anterior eye chamber, lateral ventricle and striatum $/ 4,5,11,21 /$. Behaviour and vascularisation of the intraocular grafts were observed under an operation microscope. On $30,60,90$, $120,150,180,300$ and 360 post-transplantation days, the rats were sacrificed and the transplants were processed for morphological and histochemical analysis. The number of transplants studed on each experimental day is listed in Table 1.

Tissue preparation for light and electron microscopy

After anaesthetising the animals, the intraocular grafts were rapidly dissected free from the host iris and were fixed in a buffered solution containing $4 \%$ paraformaldehyde and $2 \%$ glutaraldehyde for 24-48 hours. Intracardiac perfusion using the same fixative was done for ventricular and striatal grafts. Following perfusion, brains were sliced to identify the transplants before further processing for routine electron microscopy. Adrenal medulla of adult control rats was also processed simultaneously for comparison. One micron thick semithin sections were cut and stained with $1 \%$ toluidine blue for light microscopic analysis. Ultrathin sections of the representative areas were cut and stained with uranyl acetate and lead citrate before examination with a Philips electron microscope 300.

\section{Glyoxylic acid histochemistry}

The method of de la Torre /6/ was used to demonstrate catecholamine fluorescence in fresh transplants. Cryostat sections of 10 microns thickness were used in this method. Adrenal medulla of normal adult rats was also processed simultaneously.

\section{Tyrosine hydroxylase (TH) and dopamine beta} hydroxylase $(D B H)$ immunolabelling

After perfusion with buffered $4 \%$ paraformaldehyde and $0.1 \%$ glutaraldehyde, tissues were further fixed in buffered $4 \%$ paraformaldehyde for 12 hours. Cryostat or vibratome sections of 10-30 micron thickness were washed in PBS and preincubated in normal goat serum for 30 minutes. Incubation was for 24 hours at room temperature in primary antibody against $\mathrm{TH}$ (Incstar, U.S.A.) raised in mouse or antibody against DBH (Incstar, U.S.A.) raised in rabbit, diluted to $1: 1000$ in PBS containing $0.05 \%$ Triton-X 100. After rinsing in PBS, sections were treated with the respective secondary antibody conjugated with either fluorescin isothiocyanate (FITC) at a dilution of 1:50 or peroxidase antiperoxidase complex (The Binding Site Ltd., U.K.) at a dilution of 1:100 for 1 hour at room temperature. After washing in PBS, FITC treated sections were mounted in glycerine and were examined under a fluorescent microscope. For peroxidase anti-peroxidase immunohistochemistry, diaminobenzidine $(0.05 \%)$ was used as chromogen. After dehydrating and clearing, the sections were mounted in DPX and examined under a Zeiss Photometer III. Adrenal 
medulla of normal adult rats was also processed simultaneously for comparison. Control sections were processed without the primary antiserum.

The adjacent vibratome sections of intraventricular and intrastriatal transplants were also processed for routine electron microscopy for the structural details of the transplants used for immunolabelling.

\section{Morphometric studies}

The numerical density per unit volume (Nv) of chromaffin cells in the intraocular autografts on the 60th, 90th, 120th, 180th, 300th and 360th post-transplantation days was determined using 1 micron thick toluidine blue stained sections using an IBAS Image Analyser (Kontron, FRG). A total of 3 samples was analysed in each group. The mean values of area, perimeter and diameter of chromaffin cells were determined from 10 frames in each sample. $\mathrm{Nv}$ was calculated using the stereology program. The differences between the $\mathrm{Nv}$ of the transplanted chromaffin cells on each experimental day and the control value was statistically analysed using Student's ttest (two-tailed).

\section{RESULTS}

\section{Intraocular transplants}

Ninety percent of the autografts survived transplantation and developed rich vascularisation from the host iris within seven days. The size of the graft declined during the first week but remained constant thereafter. By about the 15th post-transplantation day, the transplants had developed a thin connective tissue capsule and were in contact with the iris.

The number of transplants with identifiable chromaffin cells on different post-transplantation days is shown in Table 1 . Based on the structural details, histo- and immunofluorescence staining characteristics and the number of such cells, the viability of chromaffin cells in different transplants was assessed.

\section{Light microscopic observations}

Up to 120 days after transplantation, the arrangement of the cells remained compact in the form of clusters and cords as in the control adrenal medulla (Figs. 1a \& b). Thereafter the cell density gradually decreased and the cells were discretely arranged in the central region in close proximity to the blood vessels. Cell shape had become polygonal or elongated. Fine connective tissue was seen in the intercellular space. Vacuoles appeared in the cytoplasm as early as 180 days (Fig. 2) and increased in size and number as the age of the transplant advanced. However, a significant number of chromaffin cells without cytoplasmic vacuolation was seen at the end of one year after transplantation.

\section{TABLE 1}

Number of autorafts studied/number of transplants with demonstrable chromaffin cells, on different posttransplantation days

\begin{tabular}{lllc}
\hline $\begin{array}{l}\text { Age of the } \\
\text { transplants } \\
\text { (days) }\end{array}$ & $\begin{array}{l}\text { Anterior } \\
\text { eye } \\
\text { chamber }\end{array}$ & $\begin{array}{l}\text { Lateral } \\
\text { ventricle }\end{array}$ & Striatum \\
\hline 30 & $10 / 8$ & $10 / 9$ & $10 / 8$ \\
60 & $11 / 8$ & $10 / 7$ & $9 / 7$ \\
90 & $9 / 8$ & $10 / 6$ & $9 / 6$ \\
120 & $9 / 9$ & $8 / 4$ & $8 / 6$ \\
150 & $11 / 10$ & $8 / 0$ & $8 / 6$ \\
180 & $10 / 10$ & $8 / 0$ & $10 / 4$ \\
300 & $9 / 9$ & $5 / 0$ & $7 / 0$ \\
360 & $10 / 10$ & $4 / 0$ & $8 / 0$ \\
\hline
\end{tabular}

\section{Electron microscopic observations}

The chromaffin cells of adult adrenal medulla used as donor tissue had scattered endoplasmic reticulum and mitochondria and a large population of uniformly distributed chromaffin granules in the cytoplasm (Fig. 3a). Each granule had an outer limiting membrane, an electron dense core and an intervening electron luscent 

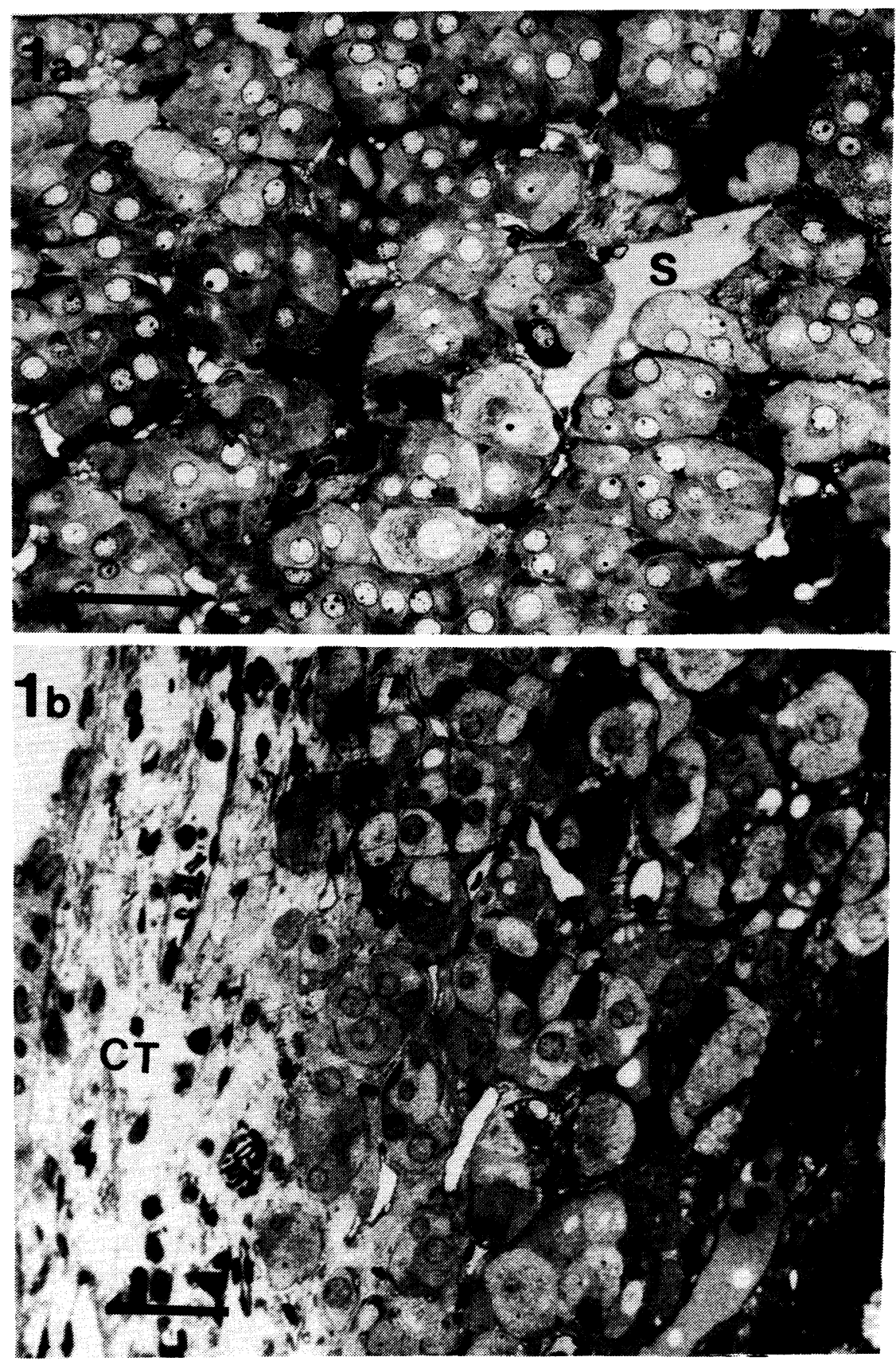

Fig. 1: (a) Photomicrograph to show compact arrangement of chromaffin cells in an adult intact adrenal medulla. (S-Sinusoid). Toluidine blue stain, Bar 40 micron.

(b) Photomicrograph of a semithin section of an intraocular adrenal medullary autograft at 120 days. Note the thick layer of connective tissue (CT) in the peripheral part of the transplant. Toluldine blue stain, Bar 20 micron.

halo. The core of the granules was either highly electron dense or moderately electron dense. These characteristics were retained by the chromaffin granules up to 120 days after transplantation (Fig. 3b). Chromaffin cells in the transplants at 180-360 days had increasinly fewer granules and other cytoplasmic organelles. The chromaffin granules present were polymorphic and had highly electron dense cores without any halo. The outer membrane was absent in most of the granules. Some of the granules were empty. Clear vacuoles and dense bodies were frequently 


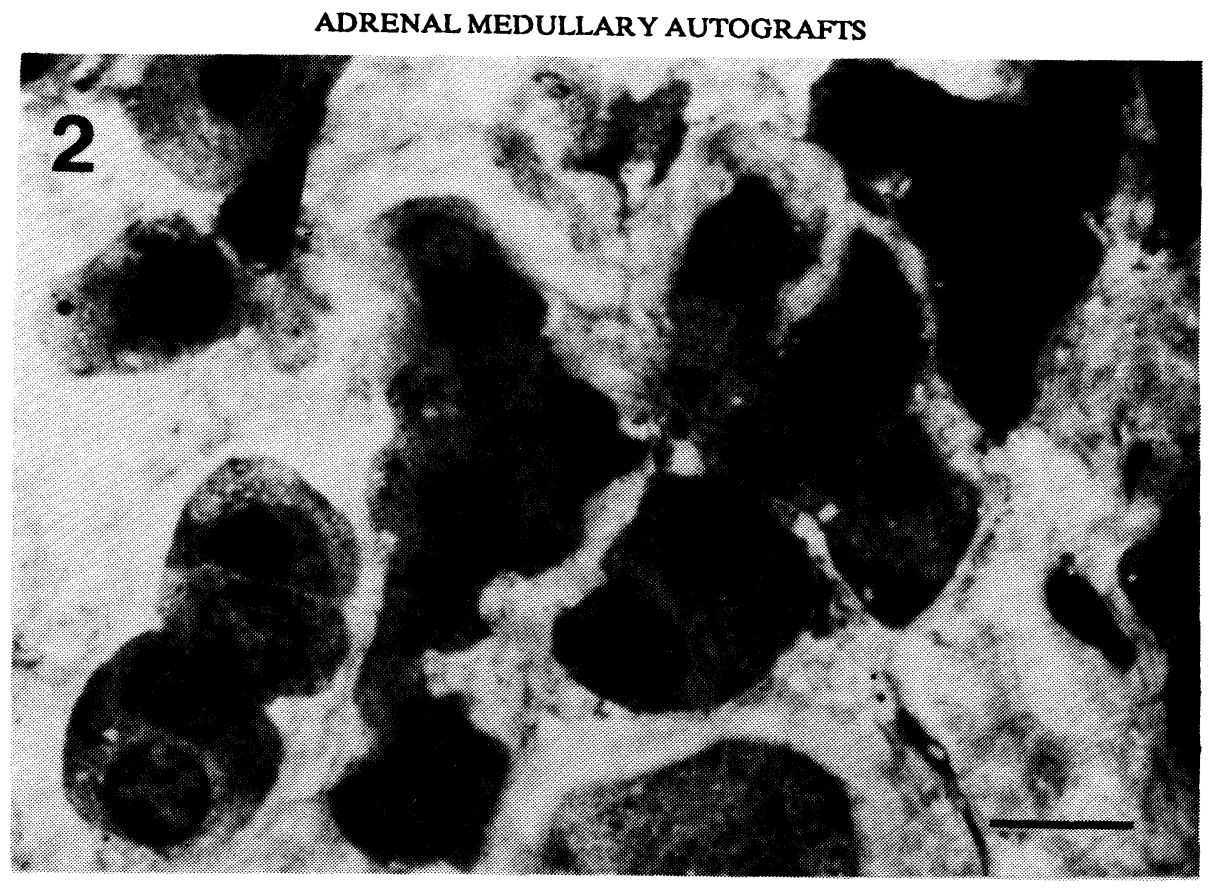

Fig. 2: 180 day-old intraocular autograft showing chromaffin cells with vacuolated cytoplasm. Toluidine blue stain, Bar 10 micron.

seen in the cytoplasm (Figs. 4a and b). Synaptic terminals with clear round vesicles were frequently seen in relation to some of the chromaffin cells (Fig. 5).

\section{Glyoxylic acid histofluorescence}

Up to 120 days, the majority of the cells showed catecholamine fluorescence (Fig. 6) and the fluorescent characteristics were comparable with that of the control adrenal medulla. Strongly fluorescent (norepinephrine) and moderately fluorescent (epinephrine) cells /19/ could be distinguished. Fluorescing cells decreased with increase in age of the transplant. In the transplants of $180-360$ days, only a few cells in clusters were seen to have weak fluorescence. Bundles of fluorescing catecholaminergic fibers were seen between the transplant and the host iris.

\section{TH and DBH immunolabelling}

Cells positive for $\mathrm{TH}$ and $\mathrm{DBH}$ immunoreactivity were seen in clusters or in isolation in all the transplants. The number of immunopositive cells was reduced as the age of the graft advanced. However, a number of discrete immunopositive cells could be seen at the end of one year (Fig. 7). Background fluorescence was strong in all the transplants studied. Both TH and $\mathrm{DBH}$ immunopositive fibers were seen between the host iris and the transplant.

\section{Morphometric studies}

Numerical density per unit volume (Nv) of chromaffin cells in the transplants at different post-transplantation days and the control are given in Table 2. The $\mathrm{Nv}$ of chromaffin cells showed a steady decline with increasing age of the transplant. The Nv of chromaffin cells in different transplants on all post-transplantation days was significantly different from the control value (Table 2).

\section{Intraventricular and intrastriatal transplants}

The number of transplants with identifiable chromaffin cells at different post-transplantation days are shown in Table 1 . Eighty percent of the transplants survived up to 60 days. 


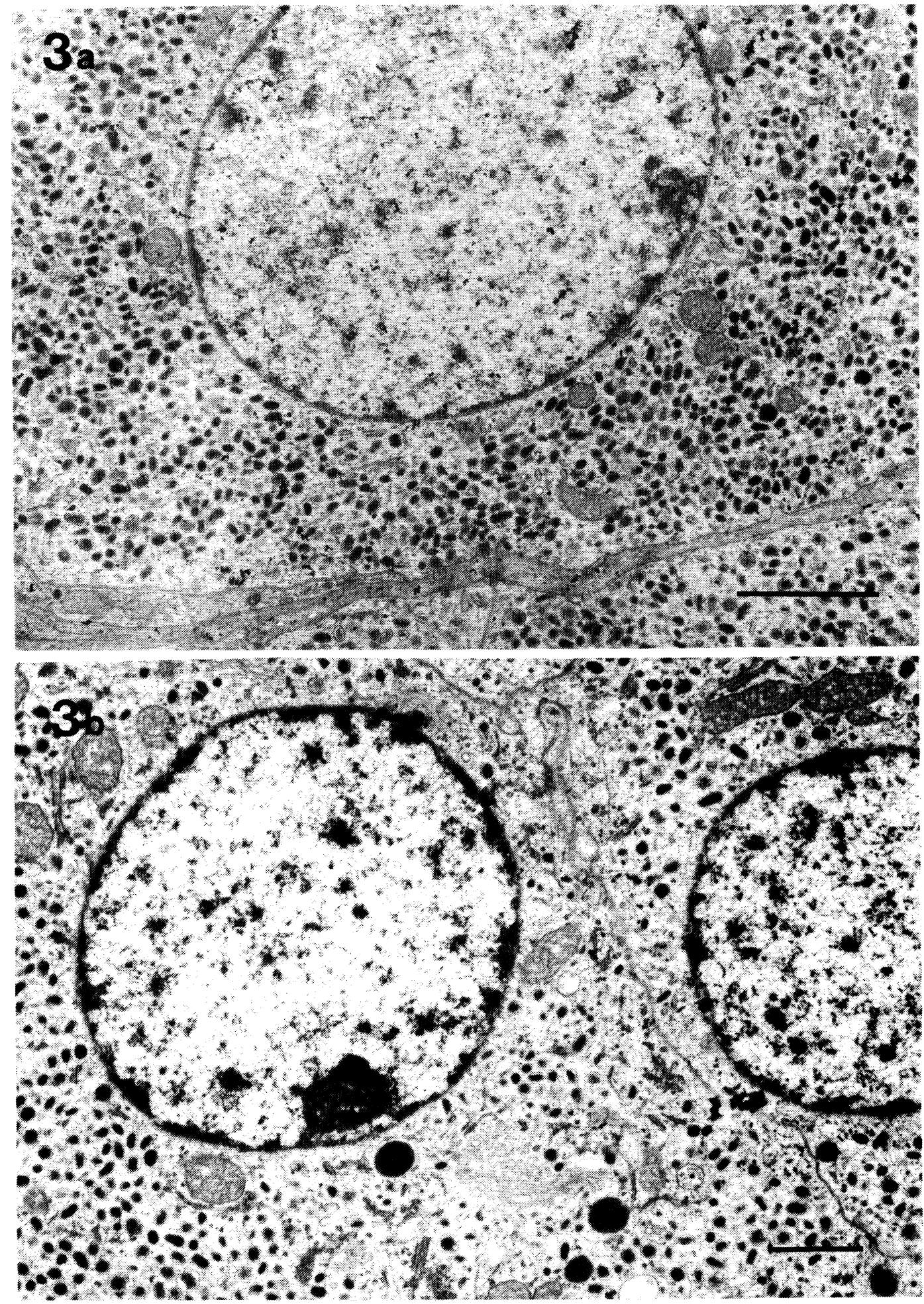

Fig. 3: (a) Electronmicrograph of chromaffin cells of intact adrenal medulla showing chromaffin granules and other organelles. Two types of granules, according to the electron density, can be seen. Bar 1 micron.

(b) Electronmicrograph of chromaffin cells from a 120 day-old intraocular autograft. Granules and other cytoplasmic organelles resemble the control chromaffin cells. Bar 1 micron. 


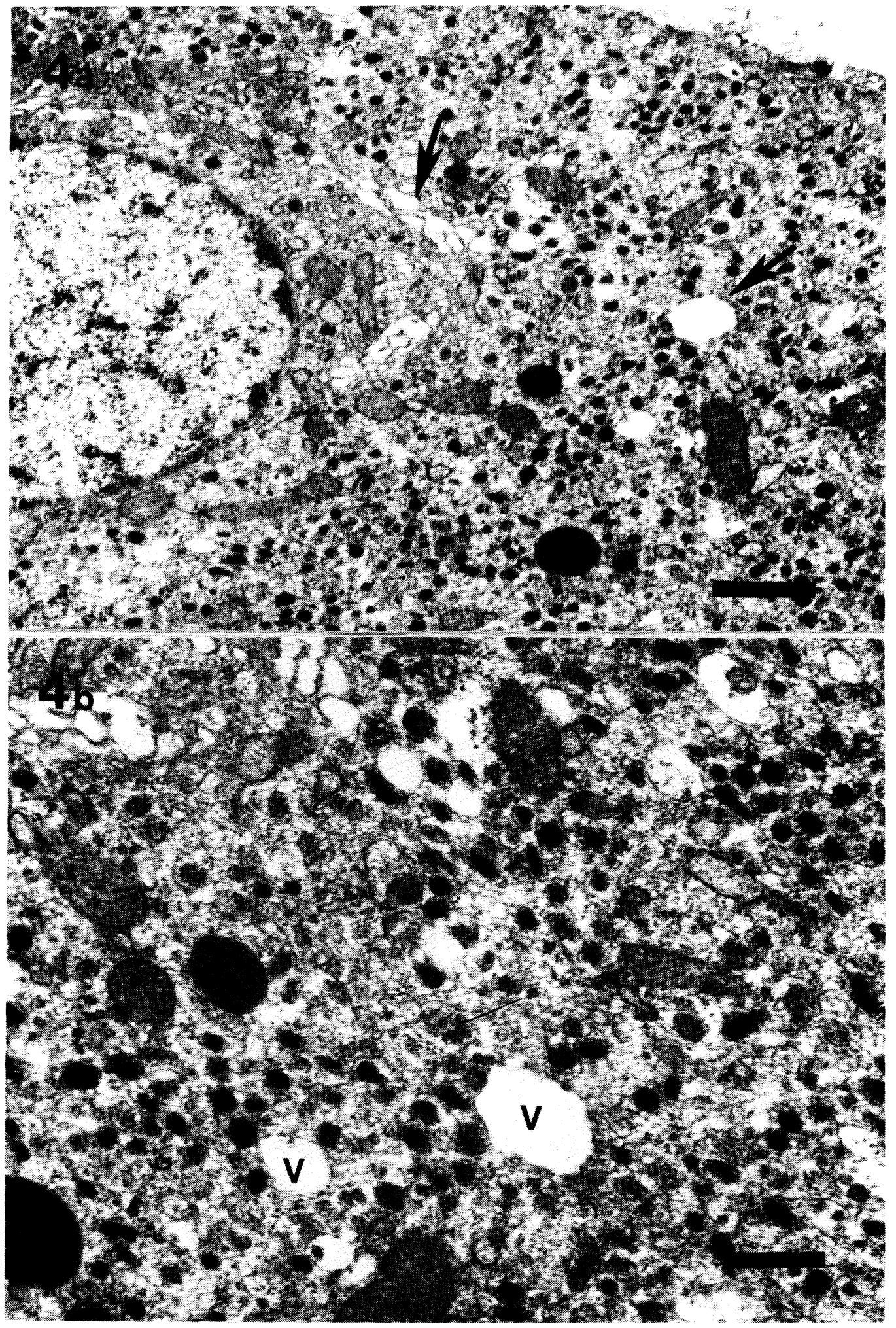

Fig. 4: (a) A chromaffin cell from a 360 day-old intraocular autograft showing fewer granules with altered structure. Note the vacuoles (arrows) in the cytoplasm. Bar 1 micron.

(b) Cytoplasmic organelles in the same chromaffin cell at higher magnification. Note the vacuoles $(V)$, dense bodies and polymorphic granules. Bar 0.5 micron. 


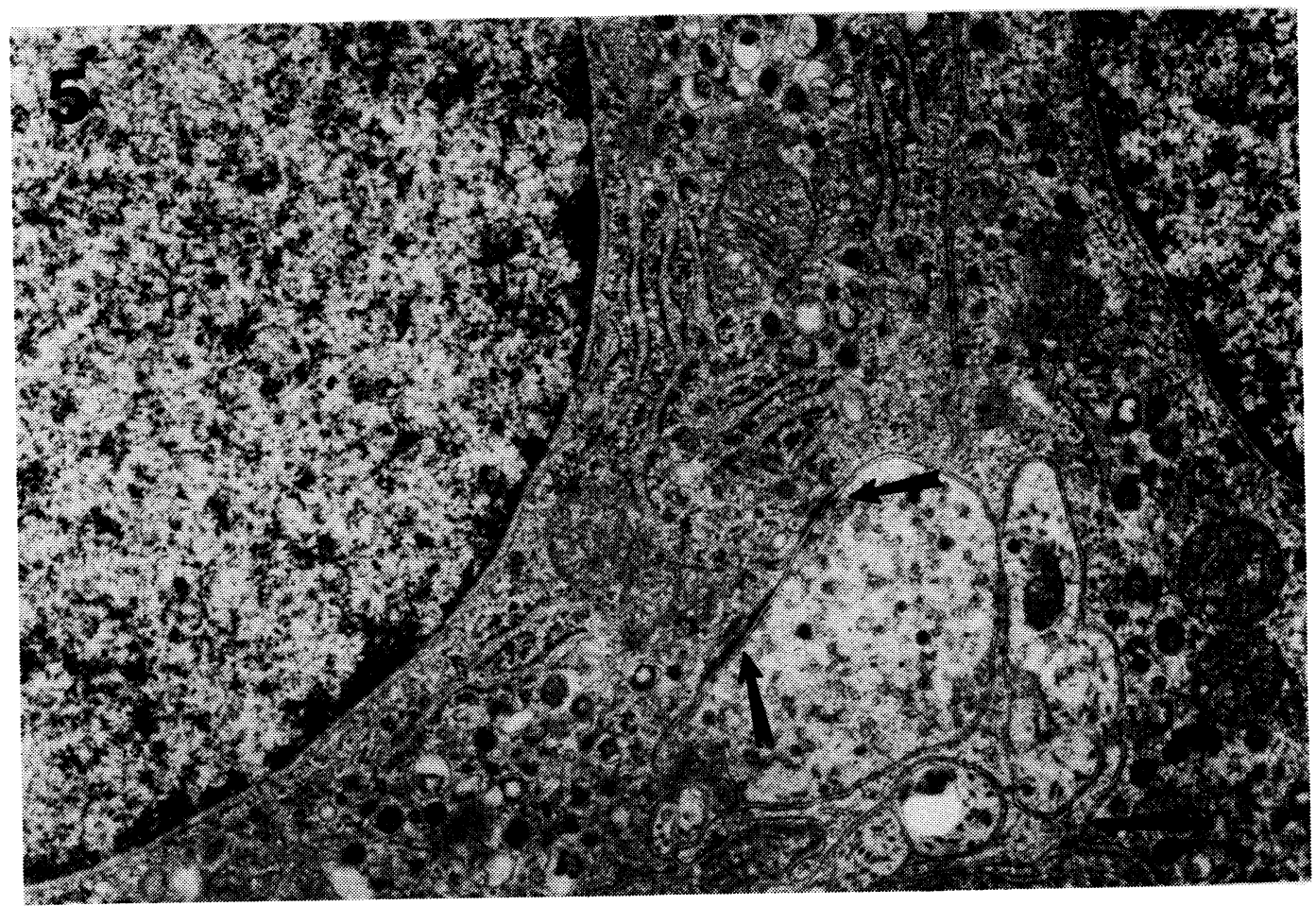

Fig. 5: Electronmicrograph from a 180 day-old intraocular transplant showing synaptic terminals (arrows) on a chromaffin cell and nerve fibers. Bar 0.5 micron.

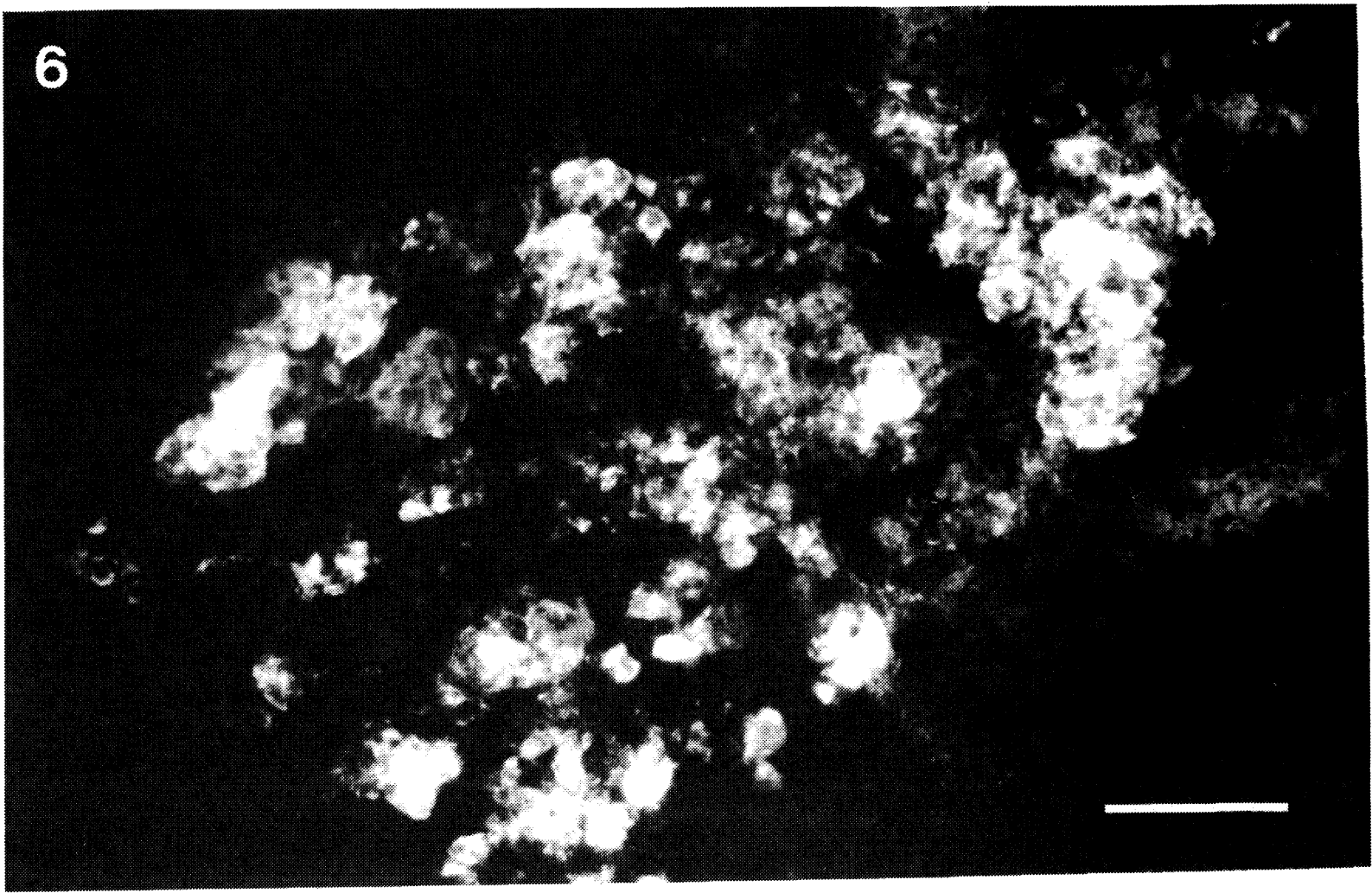

Fig. 6: Strongly fluorescent chromaffin cells in a 90 day-old intraocular autograft. Glyoxylic acid histofluorescence. Bar 100 micron. 


\section{TABLE 2}

Numerical density (Nv) of chromaffin cells in the control adrenal medulla and intraocular autografts at different post-transplantation days

\begin{tabular}{lc}
\hline & $\begin{array}{c}\text { Nv OF CHROMAFFIN CELLS } \\
\left(\times 10^{4} / \mathrm{mm}^{3} \pm \text { S.D. }\right)\end{array}$ \\
\hline $\begin{array}{l}\text { Control adrenal medulla } \\
(\mathrm{n}=3)\end{array}$ & $11.8 \pm 1.04$ \\
& \\
Post-transplatation days & \\
60 & $8.9 \pm 0.55^{* *}$ \\
90 & $7.9 \pm 0.70^{* *}$ \\
120 & $6.5 \pm 0.49^{* * *}$ \\
180 & $5.6 \pm 0.60^{* * *}$ \\
300 & $5.2 \pm 0.30^{* * *}$ \\
360 & $4.4 \pm 0.50^{*}$ \\
\hline
\end{tabular}

Student's t-test (two tailed):

* $\mathrm{p}<0.05$

$* * \mathrm{p}<0.01$

**** $\mathrm{p}<0.001$

Number of autografts studied $=3$ at each post-transplantation day

\section{Light and electron microscopic observations}

Surviving chromaffin cells with normal features were seen only in the central region of the transplants up to 60 days post-transplantation. After 60 days, the number of identifiable chromaffin cells declined rapidly. Degenerating mitochondria, vacuoles, secondary lysosomes, a reduced density of chromaffin granules (those present were polymorphic and were without the limiting membrane), and condensation of nuclear chromatin, were observed in relation to the few cells present in the transplants (Figs. 8a and b). By 150 days, no recognisable chromaffin cells were seen in the intraventricular transplants. Instead, lymphocytes, plasma cells, cell debris and macrophages were seen (Fig. 9). Intrastriatal sites continued to have a few identifiable chromaffin cells until 150 days. Thereafter only cell outlines without any normal cytology were observed in the transplant (Fig. 10a) in addition to the connective tissue cells. Vacuoles and degenerating mitochondria were seen in some of the cells. The nucleus was shrunken with dense and irregularly arranged chromatin (Fig. 10b). Cells with basement membrane were also seen among collagen fibers in three of the intrastriatal grafts at 150 days. In one of the intrastriatal transplants, myelinating axons with loose myelin lamellae and clearly visible basal laminae were seen in close association with these cells and hence these cells were identified as Schwann cells (Fig. 11).

\section{Glyoxylic acid histofluorescence}

Discrete cells and clusters of fluorescing cells were seen in the transplants until 60 days (Fig. $12 \mathrm{a})$. In addition to the fluorescing chromaffin cells, autofluorescing macrophages and debris were seen after 60 days. There was a high background of yellowish green fluorescence in relation to the intrastriatal transplants. By 150 days, only autofluorescing cells and debris were present in the ventricle. In the intrastriatal implant sites a few aminergic cell outlines could be made out up to 180 days (Fig. 12b). After 180 days, intrastriatal implant sites showed only autofluorescing cells and debris.

\section{TH and DBH immunolabelling}

A few immunopositive cells were seen in the ventricle during the early days. After 60 days only diffuse reactivity was seen in the ventricular transplants. Discrete immunopositive cells were seen at the intrastriatal implantation sites up to 150 days when treated with antibodies against $\mathrm{TH}$ and DBH. Cell outlines were not sharp because of the background reactivity (Fig. 13). After 150 days, only background reactivity was seen at the site of the transplants. Routine light and electron microscopic observations of the vibratome sections of the same 180-day old transplants revealed only cell outlines with cytoplasmic vacuoles and shrunken nuclei (Figs. $10 a$ and $b$ ). 


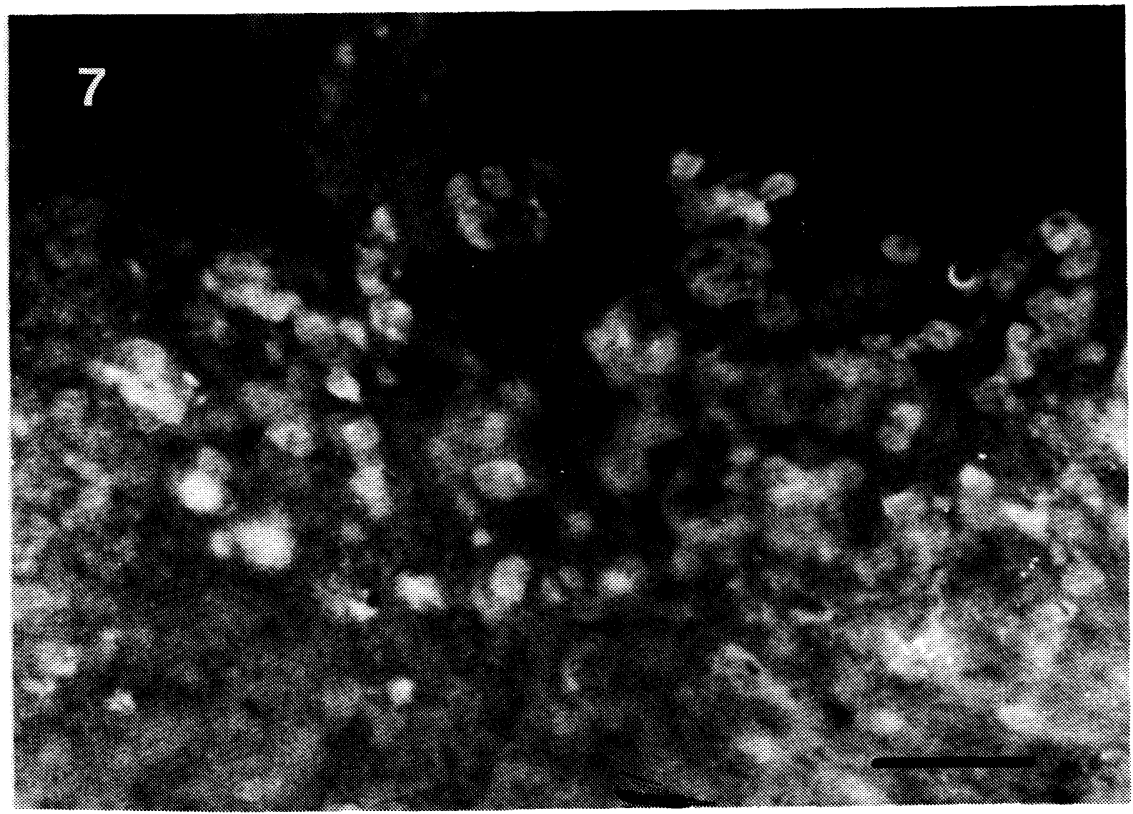

Fig. 7: A 360 day-old intraocular autograft showing discrete DBH immunopositive cells and autofluorescing debris. Bar 80 micron.

\section{DISCUSSION}

From the present study on the structural details of the transplanted adrenal chromaffin cells into the anterior eye chamber, lateral ventricle and striatum, it can be seen that these cells undergo gradual degeneration. The process of degeneration is most rapid in the ventricle and slowest in the anterior eye chamber. The changes seen in the transplants are a decline in the number of cells, polymorphism and gradual loss of the chromaffin granules and alteration in their structural integrity, vacuolation of the cytoplasm, and mitochondrial degeneration. Reduced intensity of histofluorescence and immunofluorescence, reduction in the number of fluorescing cells and the background reactivity support the cell loss and the altered cell integrity. Available studies, using fluorescent histochemistry $/ 8,9,11,12,25,26 /$ and electron microscopy /14/ of the adrenal medullary grafts in animals with prior lesions, provide conflicting reports regarding the survival and the function of these cells. Freed et al. $/ 8,9,11,12 /$ reported that chromaffin cells in allografts survived and showed encouraging functional recovery in rats with stri- atal denervation, whereas Stromberg et al. $125,26 /$ were unable to maintain these cells for long periods without NGF. Contrary to these findings, Hansen et al. /14/ found rapid degeneration of the autografted chromaffin cells in the striatum of both normal and MPTP treated Cebus monkeys within one month of transplantation. The same observation was made at autopsy in a Parkinson's patient who received an autograft of adrenal medulla /23/.

Most of the reports on the survival of the medullary chromaffin cells in the intrastriatal transplant sites are based on histofluorescence or immunofluorescence. Corroborative light microscopic and electron microscopic study was done only by Hansen et al. /14/, who report degeneration of the transplant except for a few surviving cells and chronic inflammatory reaction at the transplant sites at the end of one month. In our study, the intrastriatal transplants with diffuse $\mathrm{TH}$ and $\mathrm{DBH}$ immunopositivity on the 180 th day had chromaffin cells with pyknotic nuclei and complete degeneration of the cytoplasmic organelles when examined by routine light and electron microscopy. This indicates that these cells were not viable. So, demonstration of 


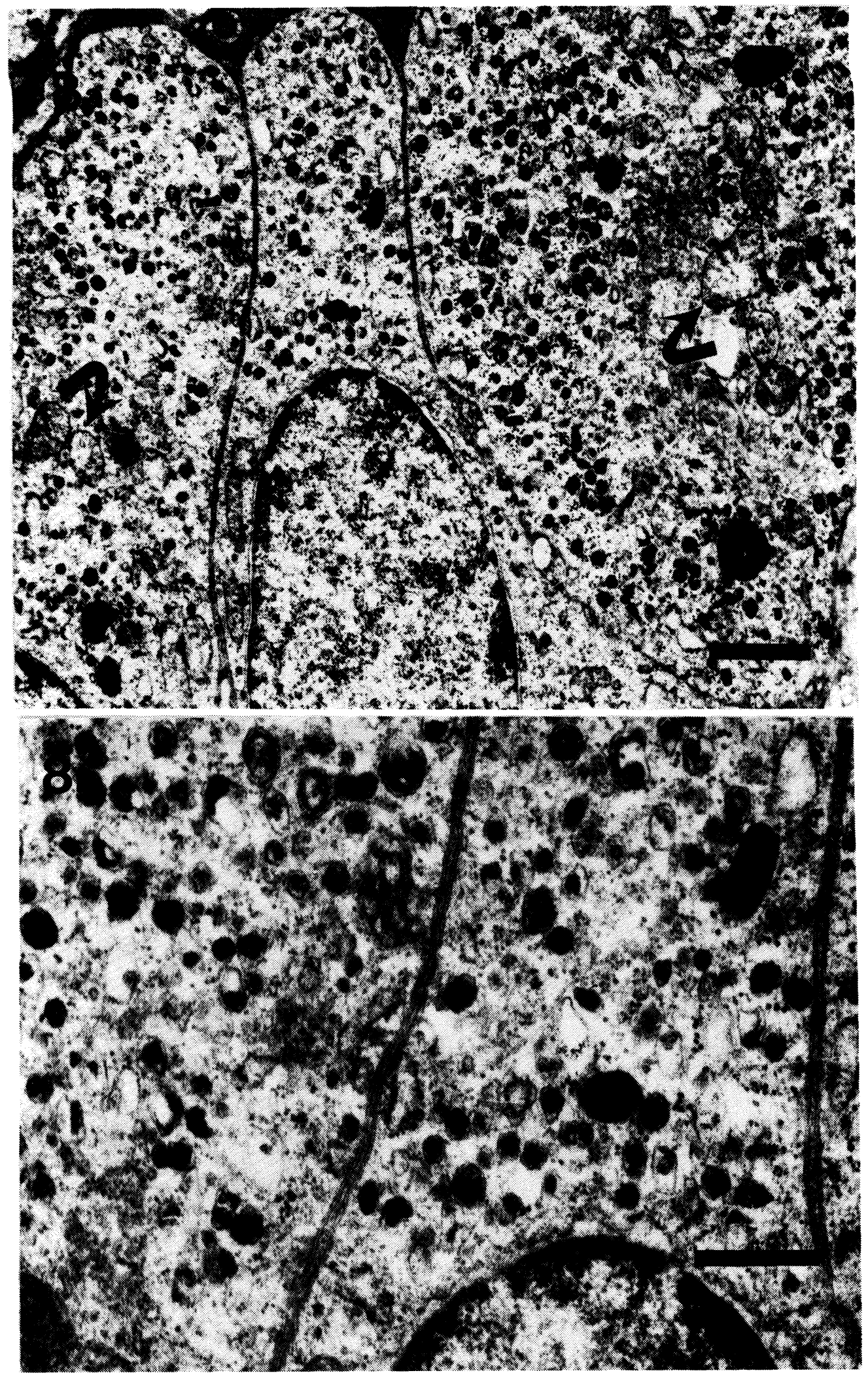

Fig. 8: (a) Electronmicrograph showing chromaffin cells in a 90 day-old intraventricular autogrart. Note the degenerating mito-chondria (curved arrows) and secondary lysosomes. Bar 1 micron.

(b) Higher magnification of the same chromaffin cells showing polymorphic vesicles and electron luscent areas in the cytoplasm. Bar 0.5 micron. 


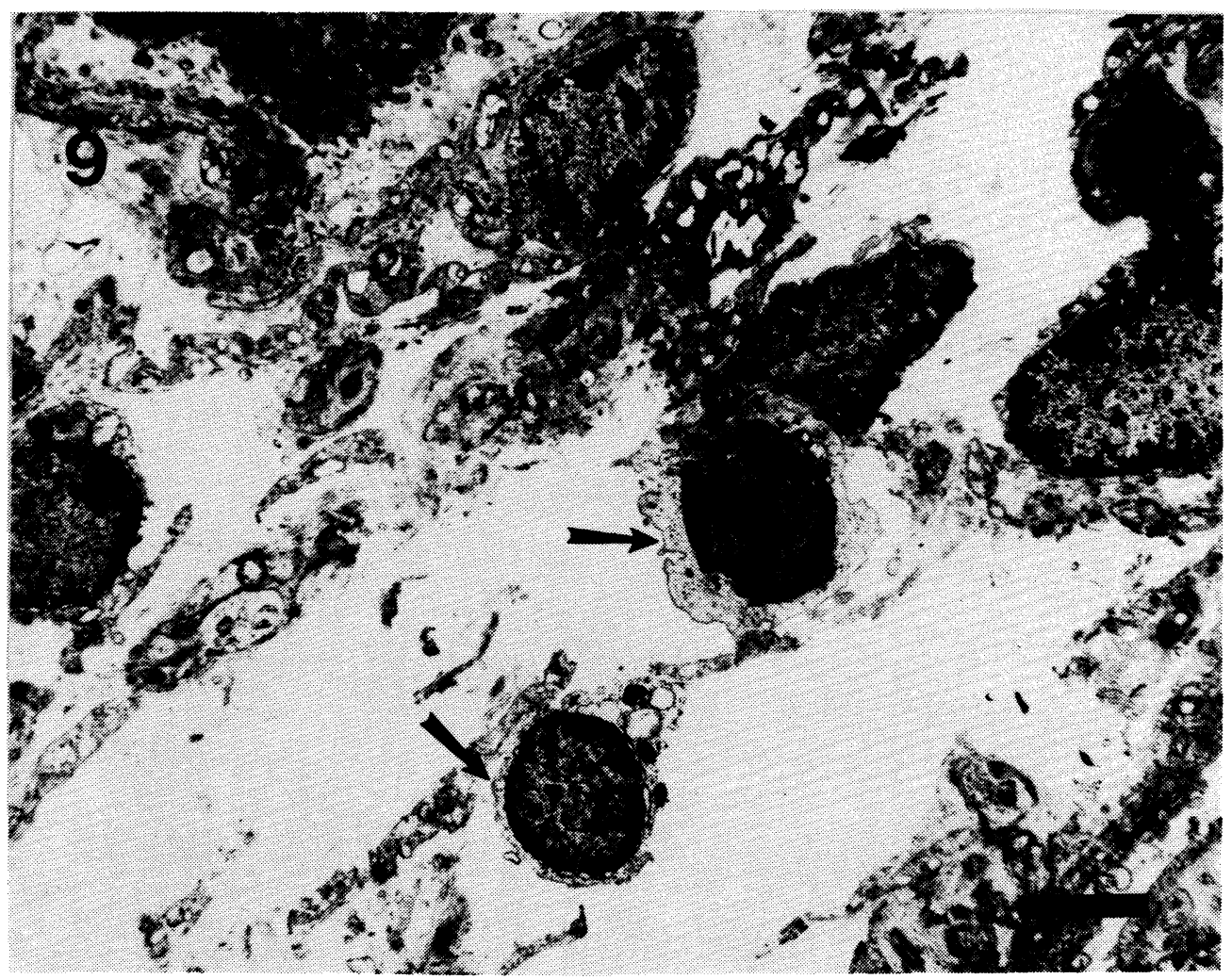

Fig. 9: Intraventricular autograft at 150 days in which only connective tissue and lymphocytes (arrows) are seen. Bar 2 micron.

the presence of catecholamines or their enzymes by histofluorescence or immunolabelling alone is not enough to establish the viability of the chromaffin cells.

Diffuse background fluorescence shown in older transplants with degenerating chromaffin cells suggests that the amines are diffusing into the surrounding extracellular space. Others have also reported diffuse fluorescence in relation to the adrenal medullary transplants $/ 7,26 /$. Amelioration of the signs reported by Freed et al. $/ 10,12 /$ and Stromberg et al. $/ 25 /$ is likely to be due to this process $/ 13 /$.

Onset and rate of degenerative changes seem to vary according to the site of transplantation. The ventricular transplants had completely degenerated by 150 days followed by the striatal grafts. Intraocular grafts had surviving cells up to 360 days. A reason for such variation could be the delay in the vascularisation of the grafts in the ventricle and striatum compared to the anterior eye chamber. Adrenal medulla being a highly vascular structure may not survive long without the physical presence of blood vessels, even though temporary nutrition could be provided by the cerebrospinal fluid. This assumption is supported by the observation that the intraocular transplants develop vascularity within the first week after grafting. Early vascularisation and also innervation by the rich nerve plexus from the iris may have preserved the chromaffin cells better and longer in the anterior eye chamber when compared to the other sites.

Despite the alteration in the cell shape as the cell number declined in the anterior eye chamber and other sites, neuronal morphology was not observed by us in the autografts as has been observed by Olson et al. in their allografts /21,22/.

Connective tissue cells and also Schwann cells in the transplant site observed by Hansen et al. $/ 14$ / and also by us may lead to later pathological changes in the central nervous system. These cells may also have some beneficial influence on 


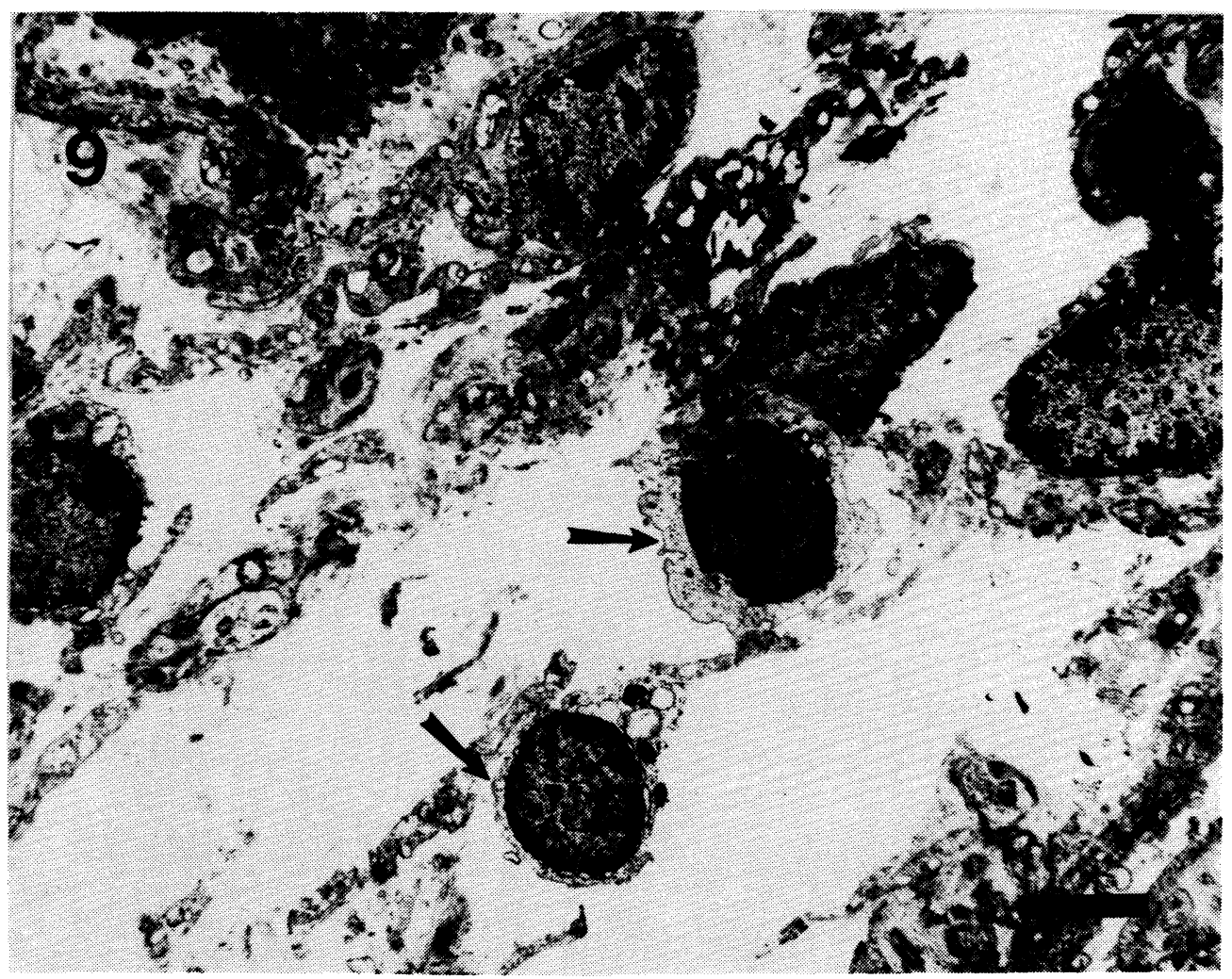

Fig. 9: Intraventricular autograft at 150 days in which only connective tissue and lymphocytes (arrows) are seen. Bar 2 micron.

the presence of catecholamines or their enzymes by histofluorescence or immunolabelling alone is not enough to establish the viability of the chromaffin cells.

Diffuse background fluorescence shown in older transplants with degenerating chromaffin cells suggests that the amines are diffusing into the surrounding extracellular space. Others have also reported diffuse fluorescence in relation to the adrenal medullary transplants $/ 7,26 /$. Amelioration of the signs reported by Freed et al. $/ 10,12 /$ and Stromberg et al. $/ 25 /$ is likely to be due to this process $/ 13 /$.

Onset and rate of degenerative changes seem to vary according to the site of transplantation. The ventricular transplants had completely degenerated by 150 days followed by the striatal grafts. Intraocular grafts had surviving cells up to 360 days. A reason for such variation could be the delay in the vascularisation of the grafts in the ventricle and striatum compared to the anterior eye chamber. Adrenal medulla being a highly vascular structure may not survive long without the physical presence of blood vessels, even though temporary nutrition could be provided by the cerebrospinal fluid. This assumption is supported by the observation that the intraocular transplants develop vascularity within the first week after grafting. Early vascularisation and also innervation by the rich nerve plexus from the iris may have preserved the chromaffin cells better and longer in the anterior eye chamber when compared to the other sites.

Despite the alteration in the cell shape as the cell number declined in the anterior eye chamber and other sites, neuronal morphology was not observed by us in the autografts as has been observed by Olson et al. in their allografts /21,22/.

Connective tissue cells and also Schwann cells in the transplant site observed by Hansen et al. $/ 14$ / and also by us may lead to later pathological changes in the central nervous system. These cells may also have some beneficial influence on 


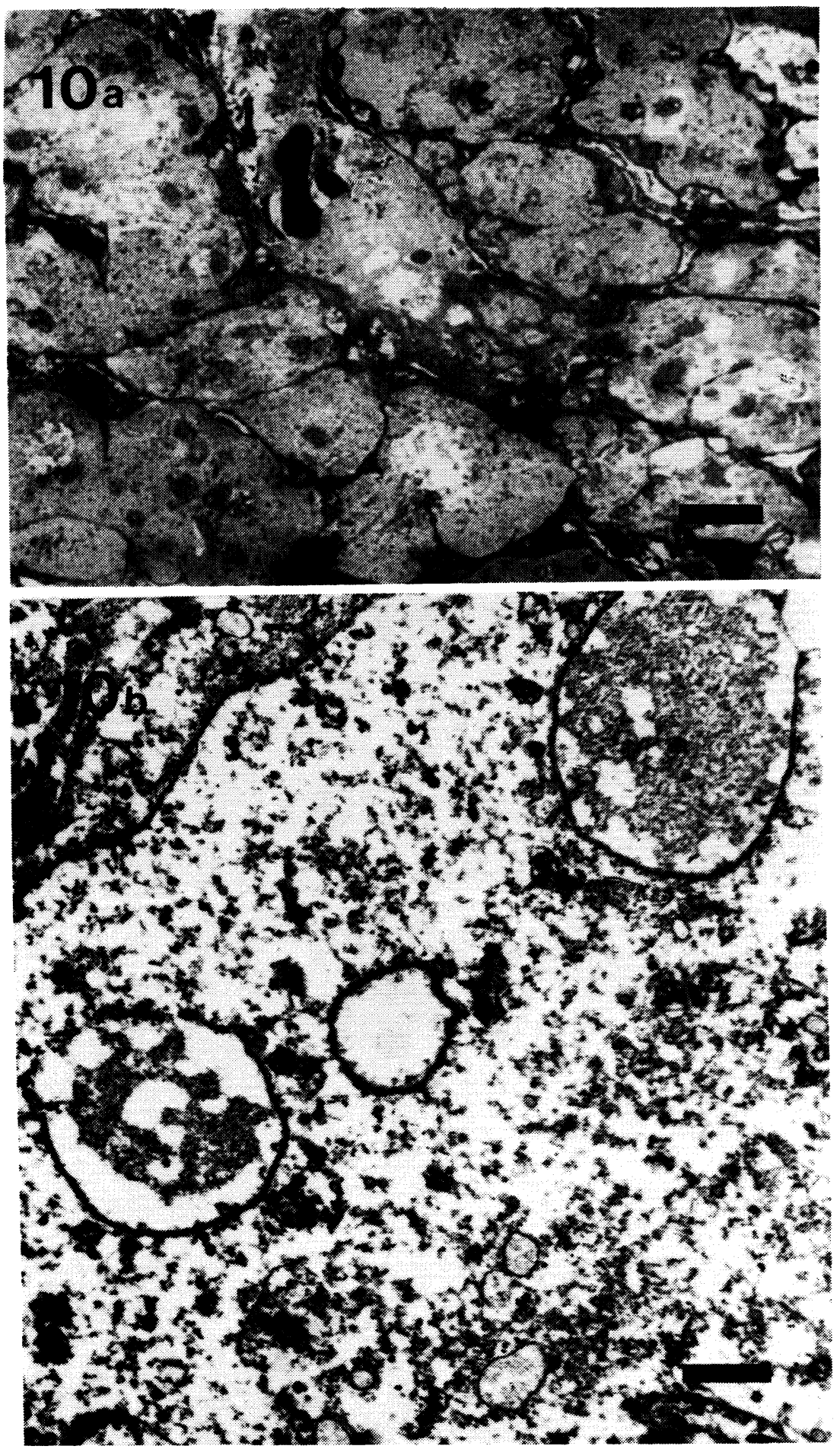

Fig. 10: (a) Intrastriatal autograft at 180 days showing chromaffin cell outlines with pyknotic nuclei and connective tissue cells. Bar 20 micron.

(b) Magnified view of the chromaffin cells in 10(a). Bar 1 micron.

the host brain. The myelinated fibers closely associated wirh the Schwann cells in one of our striatal grafts show that the Schwann cells, obviously from the adrenal graft, are capable of myelinating central axons $/ 24 /$, the source of which could be the host striatum. It could be assumed that the Schwann cells have stimulated fiber outgrowth from the host striatum by re- 


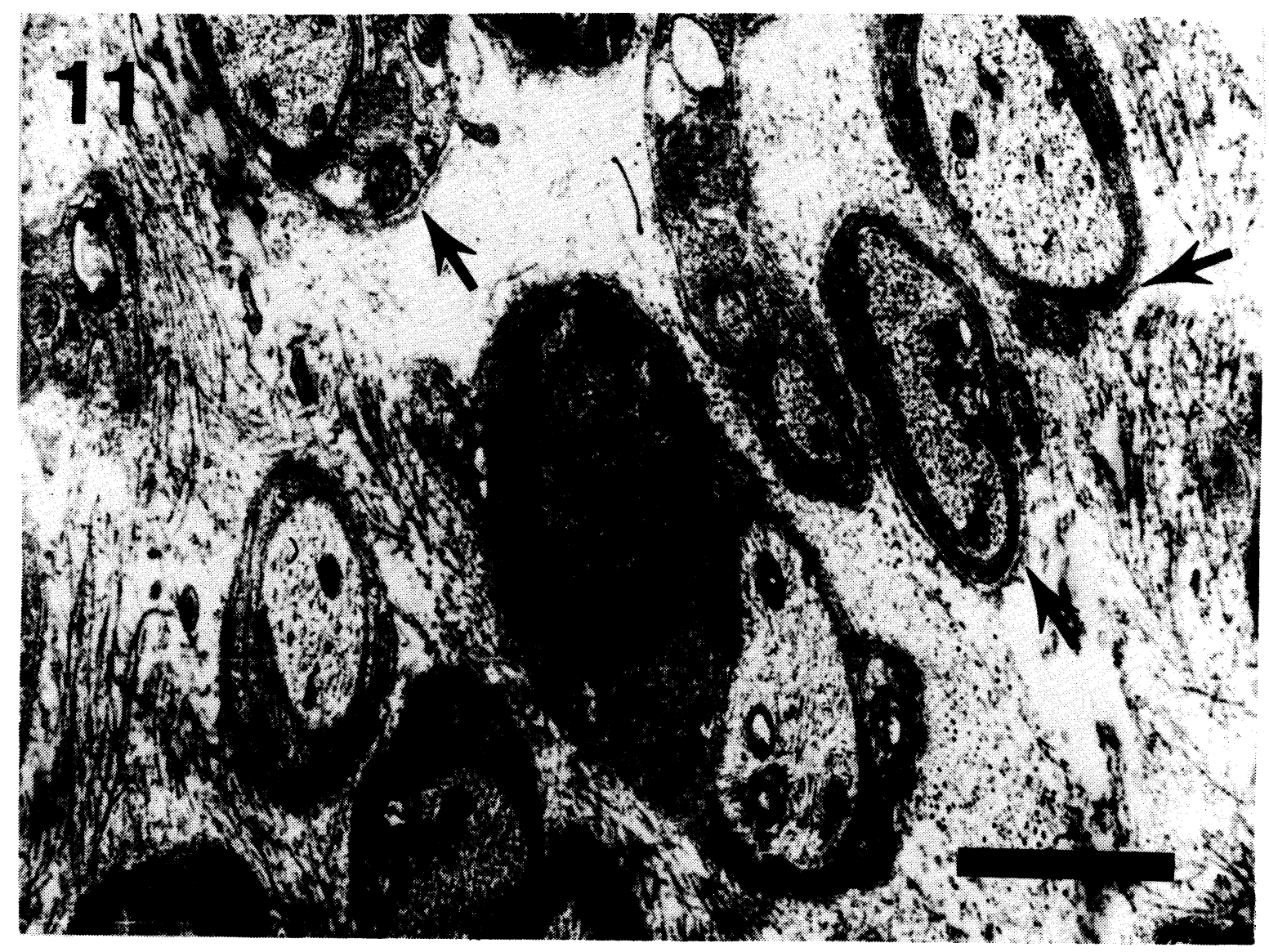

Fig. 11: Electronmicrograph to show a Schwann cell with an axon and other axons with myelin and basal laminae (arrows) in an intrastriatal autograft. Bar 1 micron.

leasing growth factors $/ 1 /$. Other investigators have reported sprouting of TH-like immunoreactive fibers at the implantation sites /3,7/. Gash and Sladek /13/ attribute this phenomenon to the influence of microglia and reactive astroglia, the host cells which respond to injury. According to Gash and Sladek /13/, Schwann cells can prolong the survival of the medullary cells. This was based on their unpublished observation of NGF reactivity of the Schwann cells derived from the peripheral nerve co-grafted with adrenal medulla and also the structural changes of the chromaffin cells in the presence of NGF secreting Schwann cells.
In conclusion, detailed morphological studies confirm that autografts of adrenal chromaffin cells degenerate at the sites preferentially chosen for treating Parkinson's patients.

\section{ACKNOWLEDGEMENT}

This project was supported by the Department of Science and Technology, Government of India. 

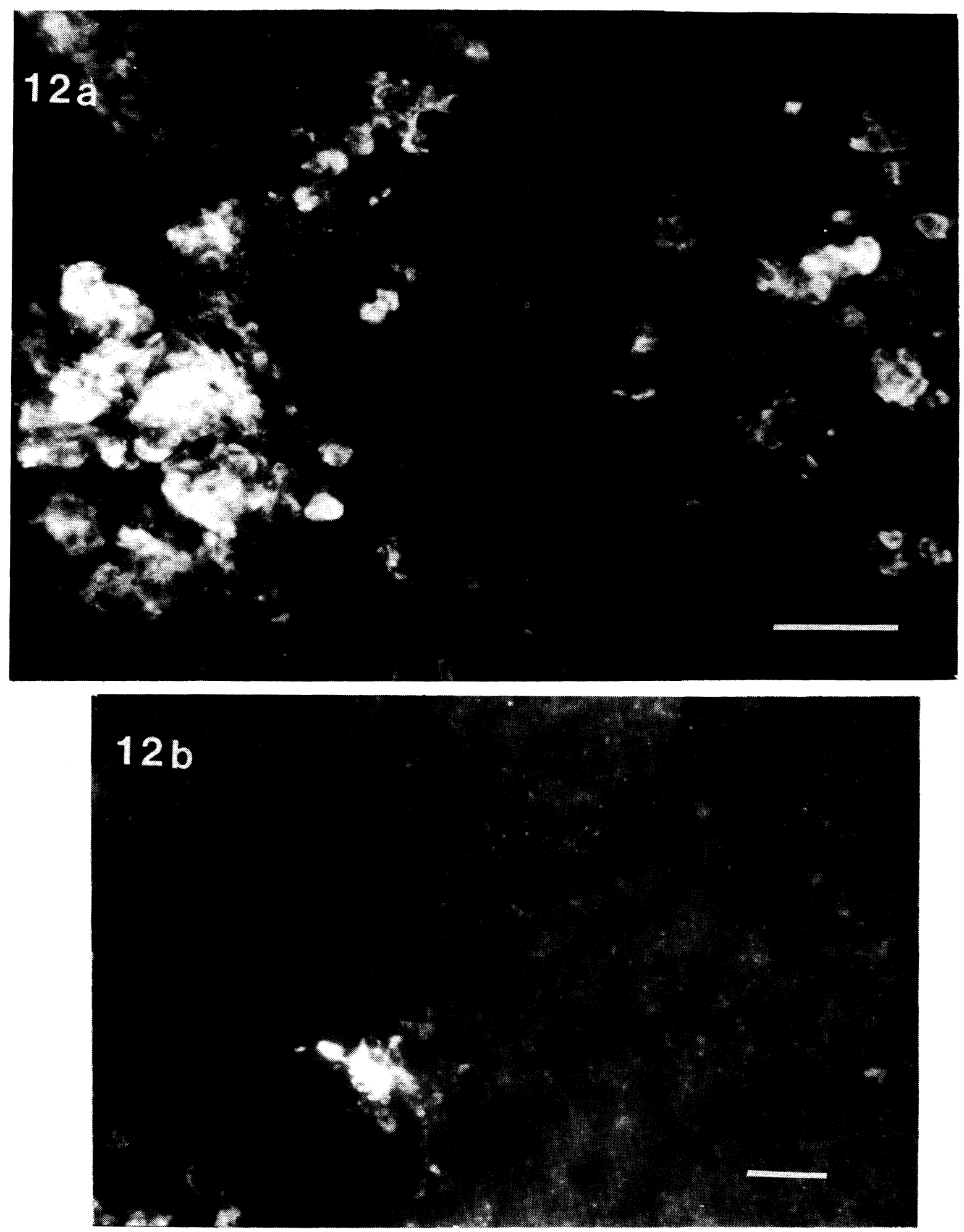

Fig. 12: (a) Photomicrograph to show clusters and dispersed fluorescing catecholaminergic cells in a 60 day-old intrastriatal autograft. Glyoxylic acid histofluorescence. Bar 20 micron.

(b) 150 day-old autograft in the striatum showing few fluorescing chromaffin cells. Bar 20 micron. 


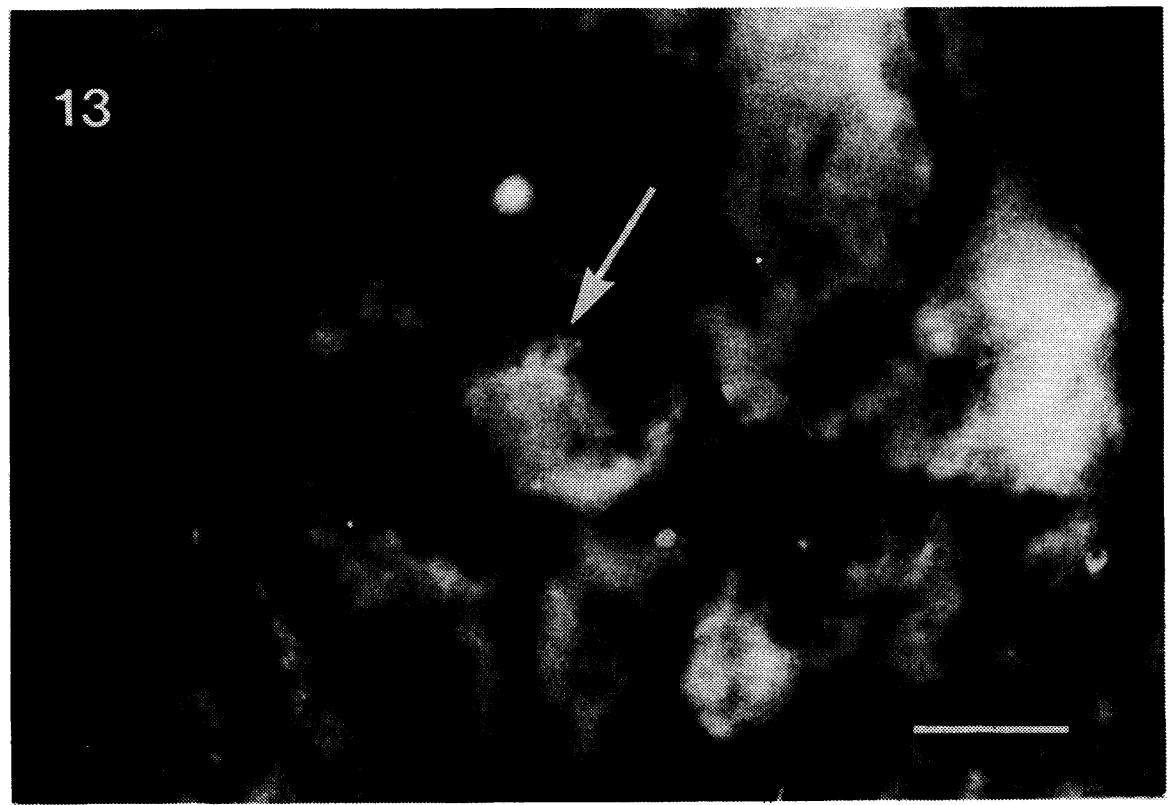

Fig. 13: TH-immunofluorescence in an intrastriatal autograft at 150 days. Bar 40 micron.

\section{REFERENCES}

1. Assouline JG, Bosch P, Lim R, Kim IS, Jensen R, Pentazis NJ. Rat astrocytes and Schwann cells in culture synthesize nerve growth factor like neurite promoting factors. Dev Brain Res 1987;31:103-118.

2. Backlund EO, Granberg PO, Hamberger B. Transplantation of adrenal medullary tissue to striatum in Parkinsonism. First clinical trials. J Neurosurg 1985;62:169-173.

3. Bankiewicz KS, Plunkett RJ, Kopin IJ, Jacobwitz DM, London WT, Oldfield EH. Transient behavioural recovery in hemiparkinsonian primates after adrenal medullary allografts. Prog Brain Res 1988;78:543-549.

4. Das GD. Intraparenchymal transplantation. In: Bjorklund A, Stenevi U, eds, Neural Grafting in the Mammalian CNS. Amsterdam: Elsevier, 1985, pp 2330.

5. Das GD, Hallas BH, Das KG. Transplantation of neural tissues in the brains of laboratory mammals: technical details and comments. Experientia 1979;35:143-153.

6. de la Torre JC. An improved approach to histofluorescence using the SPG method for tissue monoamine. J Neurosci Methods 1980;3:1-5.

7. Fiandaca MS, Kordower JH, Hansen JT, Jiao SS, Gash DM. Adrenal medullary autografts into the basal ganglia of cebus monkeys: injury induced regeneration. Exp Neurol 1988;102:76-91.

8. Freed WJ. Transplantation of tissues to the cerebral ventricles: Methodological details and rate of graft survival. In Bjorklund A, Stenevi U, eds, Neural
Grafting in the Mammalian CNS. Amsterdam: Elsevier, 1985, pp 31-40.

9. Freed WJ, Cannon-Spoor HE, Krauthamer E. Intrastriatal adrenal medulla grafts in rats: Long term survival and behavioural effects. J Neurosurg 1986;65:664-670.

10. Freed WJ, Farouk KH, Spoor E, Morihisa JM, Olson L, Wyatt RJ. Catecholamine content of intracerebral adrenal medulla grafts. Brain Res 1983;269:184-189.

11. Freed WJ, Hoffer BJ, Olson L, Wyatt RJ. Transplantation of catecholamine containing tissues to restore the functional capacity of the damaged nigrostriatal system. In Sladek JR, Gash DM, eds, Neural Transplants-Development and Function. New York and London: Plenum Press, 1984, pp 373-406.

12. Freed WJ, Morihisa E, Spoor E, Hoffer BJ, Olson L. Transplanted chromaffin cells in rat brain reduce lesion-induced rotational behaviour. Nature 1981;292:351-352.

13. Gash DM, Sladek JR. Neural transplantation: Problems and prospects - where do we go from here? (Editorial), Mayo Clin Proc 1989;64:363-367.

14. Hansen JT, Kordower JH, Fiandaca MS, Jiao SS, Notter MFD, Gash DM. Adrenal medullary autografts into the basal ganglia of cebus monkeys: Graft viability and fine structure. Exp Neurol 1988; 78:543-549.

15. Lewin R. Dramatic results with brain grafts. Research News, Science 1987;237:245-247.

16. Lindvall $O$. Transplantation into the human brain: Present status and future possibilities. J Neurol Neurosurg and Psychiatry (special supplement) 1989;39-54. 
17. Lindvall O, Dunnett SB, Brundin P. Transplantation of catecholamine producing cells to the basel ganglia in Parkinson's disease: experimental and clinical studies. In Rose FC, ed, Parkinson's Disease: Clinical and Experimental Advances. London: John Labbey \& Co. Ltd., 1987, pp 189-206.

18. Madrazo I, Drucker-Colin R, Diaz V, MartinezMarta J, Torres C, Beurril JJ. Open microsurgical autografts of adrenal medulla to the right caudate nucleus in two patients with intractable Parkinson's disease. N Engl J Med 1987;316:831-834.

19. Molinoff PB, Axelrod JA. Biochemistry of catecholamines. Ann Rev Biochem 1971;40:465-500.

20. Morihisa JM, Nakamura RK, Freed WJ. Adrenal medullary grafts survive and exhibit catecholamine specific fluorescence in the primate brain. Exp Neurol 1984;84:643-653.

21. Olson L. Fluorescence histochemical evidence for axonal growth and secretion from transplanted adrenal medullary tissue. Histochemie 1970;22:1-7.

22. Olson L, Seiger A, Freedman R, Hoffer BJ. Chromaffin cells can innervate brain tissue: evidence from intraocular double grafts. Exp Neurol 1980;70:414-426.

23. Peterson DI, Price ML, Small CS. Autopsy findings in a patient who had an adrenal to brain transplant for Parkinson's disease. Neurology 1989;39:235-238.

24. Sasaki M, Ide C. Demyelination and remyelination in the dorsal funiculus of the rat spinal cord after heat injury. J Neurocytol 1989;18:225-239.
25. Stromberg I, Herrera-Marschitz M, Hultgren L, Ungerstedt U, Olson L. Adrenal medullary implants in the dopamine denervated striatum. 1. Acute catecholamine levels in grafts and host caudate as determined by HPLC electrochemistry and fluorescence histochemical image analysis. Brain Res 1984;297:4151.

26. Stromberg I, Marschitz MH, Ungerstedt U, Ebendal T, Olson L. Chronic implants of chromaffin tissue into the dopamine denervated striatum: Effects of NGF on graft survival, fiber growth and rotational behaviour. Exp Brain Res 1985;601:335-349.

27. Tischler AS, Greene LA. Phenotypic plasticity of pheochromocytoma and normal adrenal medullary cells. In: Eranko O, Soinila S, Paivarinta H, eds, Histochemistry and Cell Biology of Autonomic Neurons, SIF Cells and Paraneurons. New York: Raven Press, 1980, pp 61-68.

28. Unsicker $\mathrm{K}$, Krischner B, Othen V, Thoenen $H$. NGF induced fiber outgrowth from isolated rat adrenal chromaffin cells: impairment by glucocorticoids. Proc Natl Acad Sci USA 1978;75:3498-3502.

29. Unsicker K, Rieffert B, Ziegler W. Effects of cell culture conditions, nerve growth factor, dexamethasone and cyclic AMP on adrenal chromaffin cells in vitro. In Eranko O, Soinila S, Paivarintha $\mathrm{H}$, eds, Histochemistry and Cell Biology of Autonomic Neurons, Advances in Biochemical Psychopharmacology, vol.25. New York: Raven Press, 1980, pp 51-59. 

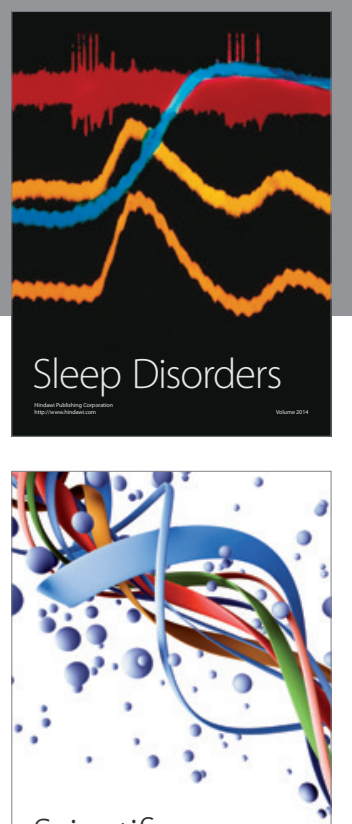

Scientifica
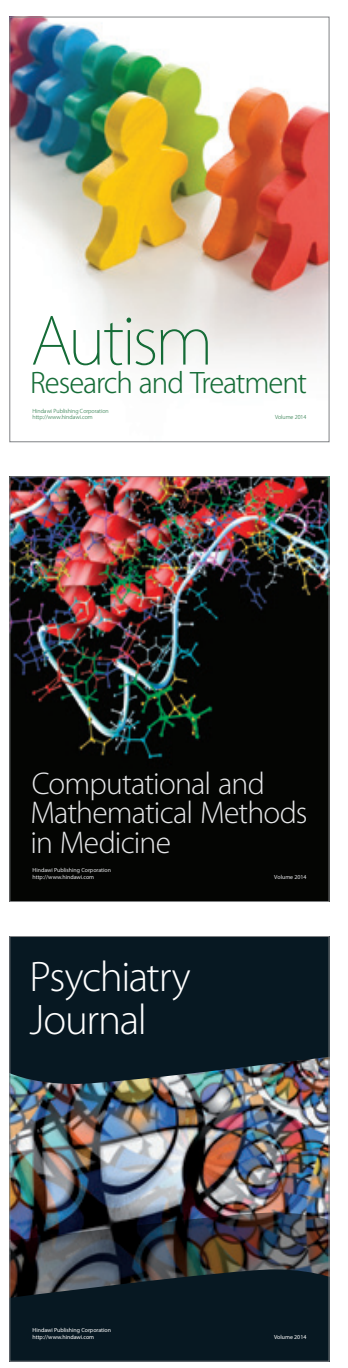
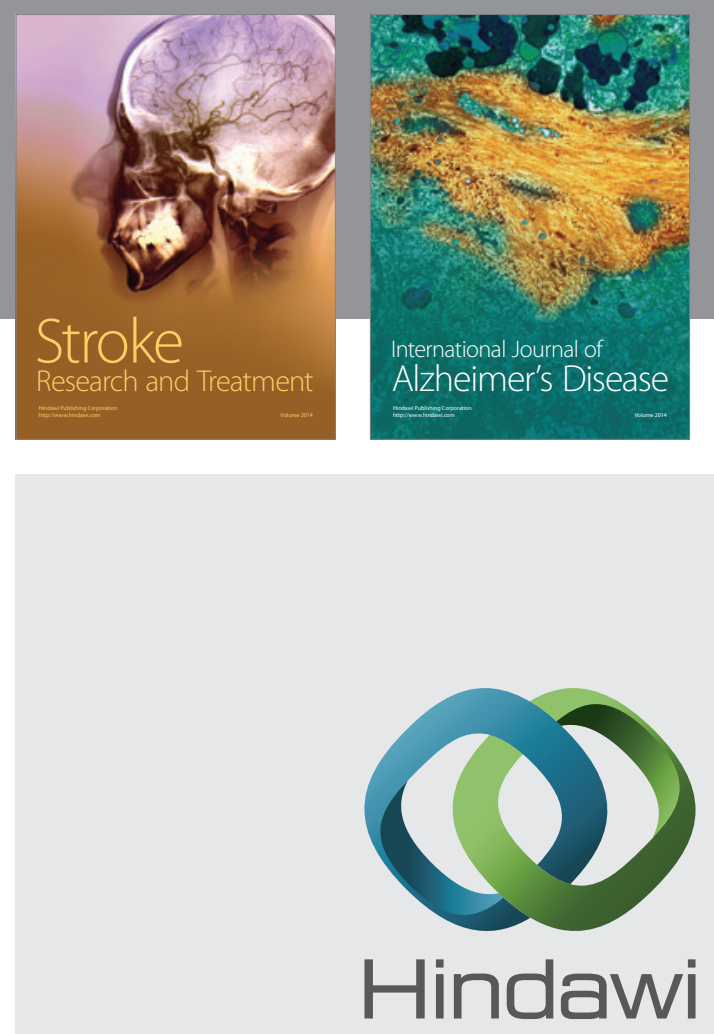

Submit your manuscripts at

http://www.hindawi.com
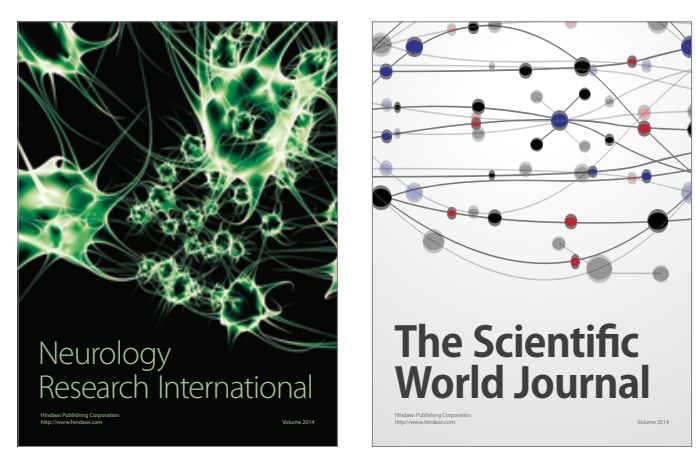

The Scientific World Journal

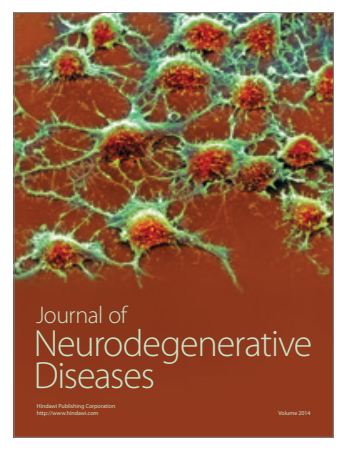

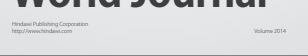

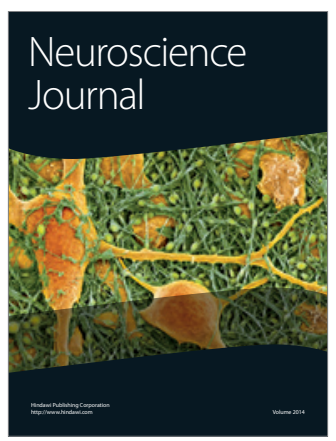

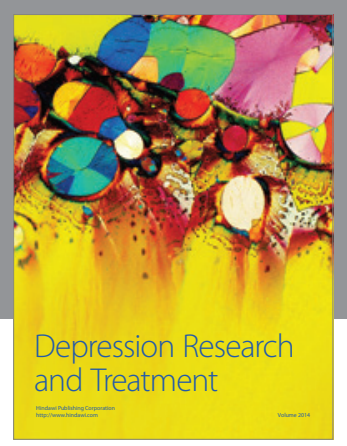
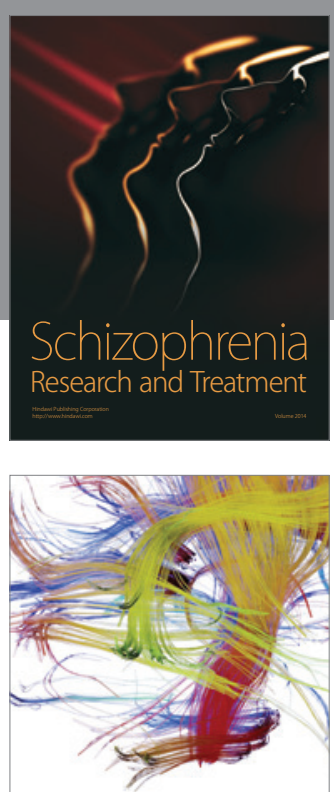

Brain Science

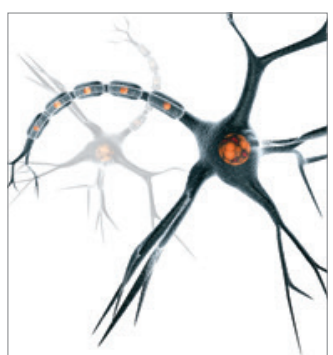

Neural Plasticity
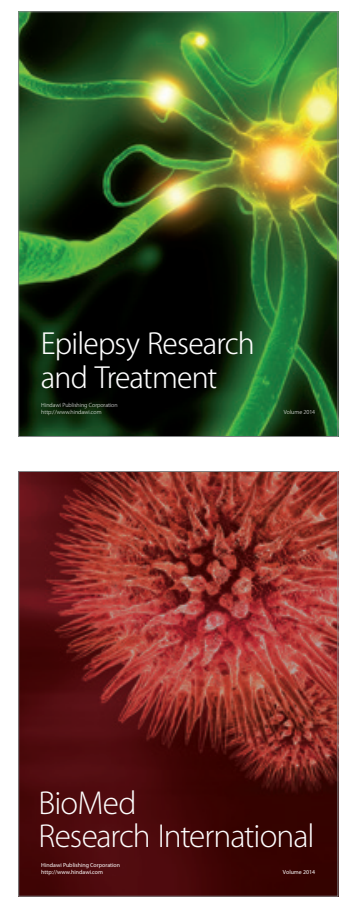

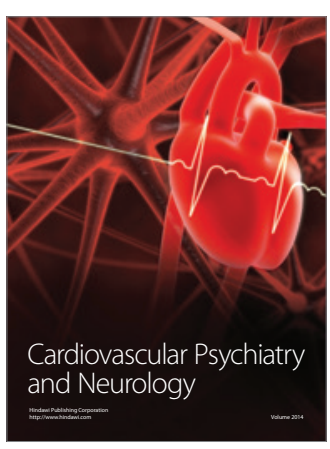

Parkinson's

Disease
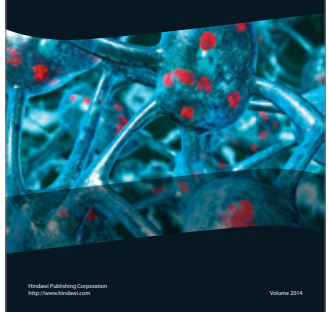